\title{
IMAGE OF THE GERMAN ENEMY AS PERCEIVED BY RUSSIAN ARMY SOLDIERS DURING WORLD WAR I
}

The article analyses the sociocultural context and factors of the initial shaping and further evolution of the image of a German as perceived by Russian army soldiers during World War I (1914 - February 1917). The article reveals the specific role and characteristics of the official propaganda used to create the image of the German enemy and its reflection within a soldier's perception. The author examines verbal and nonverbal symbolic representations of the image of a German in a soldier's consciousness and the correlation between the image of a German, the enemy from outside and the "inner German". The author's interpretation of published and unpublished sources both of official and personal nature (materials from the police department, statistics, folklore, memoires, letters, diaries, periodicals) is underpinned by the conceptual techniques of imagology and sociocultural history. The author reveals the key characteristics and the evolutionary development of the image of the German enemy in popular perceptions of Russian army soldiers between 1914-1917.

Keywords: patriotic propaganda, Russian army, soldiers, Germany, lubok ${ }^{1}$, German, “inner German”, enemy image, enemy image evolution.

Статья посвящена анализу социокультурного контекста, факторов формирования и эволюции образа немца в сознании солдат русской армии в условиях Первой мировой войны. Показаны специфические черты и роль официальной патриотической пропаганды в формировании образа немца-врага, ее преломление в восприятии солдат. Рассмотрены вербальные и невербальные символические репрезентации образа немца в сознании солдат, корреляция образов немца - внешнего врага и «внутреннего немца». На основе концептуальных подходов имагологии и социокультурной истории интерпретируются опубликованные и

\footnotetext{
${ }^{1}$ A lubok (plural Lubki, Cyrillic: Russian: лубок, лубочная картинка) is a Russian popular print, characterized by simplegraphics and narratives derived from literature, religious stories and popular tales. Lubki prints were used as decoration in houses and inns. Early examples from the late 17 th and early 18 th centuries were woodcuts, then engravings or etchings were typical, and from the mid-19th century lithography. They sometimes appeared in series, which might be regarded as predecessors of the modern comic strip. Cheap and simple books, similar to chapbooks, which mostly consisted of pictures, are called lubok literature or (Cyrillic: Russian: лубочная литература). Both pictures and literature are commonly referred to simply as lubki. The Russian word lubok derives from $l u b-$ a special type of board that pictures were printed on. See http://en.wikipedia.org/wiki/Lubok
} 
неопубликованные источники официального и личного происхождения (материалы Департаментаполиции, статистика, фольклор, воспоминания, письма, дневники, периодическая печать). Выявлены основные черты и направленность эволюции образа немца-врага в массовом сознании солдат русской армии в указанный период.

Ключевые слова: патриотическая пропаганда, русская армия, солдаты, Германия, лубок, немец, «внутренний немец», образ врага, эволюция образа врага.

Studying the sociocultural history of World War I in the West in the last three decades resulted in the publication of a number of papers on its different aspects, including issues of mutual perceptions between adversaries [Hubertus, 1995; Stites; Liulevicius; Lipp; Norris; Ziemann; etc.]. Studies like these in Russia only started in the post-soviet time when emphases have shifted from revealing the preconditions for the revolution to the examination of cultural and social practices of wartime. Papers published by S. V. Tyutyukin, Yu. I. Kiryanov, E. S. Senyavskaya, B. I. Kolonitsky etc., demonstrate a decisive move towards the re-evaluation of cultural and psychological aspects of Russia's part in the First World War. The nature of patriotic attitudes, the psychology of the front line and rear, and the system of beliefs and perceptions conditioned by the involvement in the war have become subjects of specialized studies [Тютюкин; Кирьянов; Сенявская, 1999; Колоницкий, 1999, etc.]. Assiduous attention to the range of problems pertaining to imagology is a manifestation of the "cultural turn" in contemporary Russian historiography of World War I. The first papers on the image of the "alien" and enemy just before and during World War I were published in the 1990s [Сенявская, 1997; Сергеев]. Some monographic studies and articles, which consider the problems of national ideology and identity, public and individual perceptions of war, authority, enemies and allies of one's own state in relation to World War I, were published at the beginning of the $21^{\text {st }}$ century [Поршнева; Сенявская, 2006; Носков, Колоницкий, 2010; Голубев, Поршнева, etc.]. This subject is, however, far from having been exhausted and requires further research not only in previously unexamined sources but also with new interpretations of documentary evidence introduced by scholars.

The image of adversaries and allies took shape in the Russian consciousness just before the war as international relations deteriorated, creating two hostile blocs and establishing the ideological and psychological preconditions for total war. S. Ferster argues convincingly that without the direct support of civil society the transition to this type of war, which left its imprint on an entire era, would have been impossible [Ферстер, с. 25]. The national "I" as well as both the friendly and adversarial "Other" had become more clearly defined at the turn of $19^{\text {th }}$ and $20^{\text {th }}$ centuries, establishing conditions for not only the emergence of coalitions of hostile nation-states but also the consolidation of the nation-state. At the time the mechanism 
for shaping foreign political stereotypes was particularly active, not only through mass propaganda but also through the actualisation of perceived ethnic images and prejudices, cultural preferences and values.

The specifics of Russia's historical situation at the beginning of the $20^{\text {th }}$ century determined the ultimate weakness in influencing public perceptions with official "patriotic" propaganda and the ideological and psychological preparations for the war. This was determined by a number of factors: concerns for inadequate perception by the masses of the antiGerman propaganda, which should be capable of provoking a sufficiently volatile social response; the country being not quite ready for war due to the incomplete implementation of military technological reforms; the anticipation of possible tragic consequences of an unsuccessful war; Germanophile attitudes of a part of the Russian ruling elite and dynastic connections of the Russian Royal House; apprehension of promoting further the pan-Slavism attitudes; unsuccessful propaganda experiences of "police socialism"; distrust for the "public", the intellectual forces which could have performed this work more efficiently [Stites, p. 9]. The panSlavism propaganda that was not encouraged by the government did not match the examples of popular patriotism and was not oriented to the masses at large [Hubertus, 1991, p. 4].

The development of ideological substantiation for Russia's participation in the war against the German bloc had begun after the country entered the conflict on the $19^{\text {th }}$ of July 1914 and was promoted, similar to other countries, by insisting upon the protection of the homeland, its people, its vital interests and values against interference by other states. In his Imperial Manifestos dated 20 and 26 July 1914, declaring the war with Germany and Austria-Hungary, Nicholas II indicated the causes for and the nature of Russia's participation in the European conflict: the protection of the country's territory, its honour, dignity, position amongst other great states, as well as for "Slavic brothers of the same blood and the same faith" ("единокровных и единоверных братьев-славян”) [Царские слова к русскому народу, с. 1] $]^{2}$.

On the whole the general mobilisation in Russia had been successful; $96 \%$ of those subject to conscription had appeared before mobilisation committees ${ }^{3}$. Before the general mobilisation, Russian armed forces counted 1,423,000 soldiers; after its completion and additional drafts by the end of 1914, this count increased to six and a half million recruits [Россия в мировой войне, с. 18]. Almost $75 \%$ of all the conscripts at the time of the first week of the mobilisation were peasants [Berkevich, c. 13]. The proportion of peasants increased over time; by 1917, of the 15.5 million conscripts, over 12.8 million had been drafted from the countryside [Pocсия в мировой войне, с. 4,49$]$.

\footnotetext{
2 Tsar's words to the Russian people.

3 The mobilisation was accompanied with some disturbances amongst the lower ranks predominantly in the form of trashing state-owned wine shops which was a reaction to the violation of the traditional conscript send-off ritual. See: [Поршнева, с. 91-94, 134-135].
} 
The attitude of Russian soldiers to the war, to enemies, and to allies of their state in many respects was determined by the particular and fundamental beliefs and perceptions of the peasants. Peasants, and a majority of workers, perceived war as fate, a trial sent by God, a natural disaster and impossible to counteract [Поршнева, с. 88-89, 133]. With the country's impending engagement in war, the authoritarian, patriarchal political culture determined that the formula, "For Faith, Tsar and Fatherland", closely connected to the traditional model of behaviour in the new conscripts.

From the moment of Russia's engagement in the war, the official propaganda shaped the external image of the enemy by employing all available means. Attention had been focused on the enemy's culpability at the onset of war, demonstrating its unfair annexationist goals [Альбом героев войны, с. 2-5; Россия борется за правду, с. 6-11]. The provincial press was not far behind the main periodicals in cultivating an antiGerman pathos [Пермские ведомости; Оренбургская жизнь; Уральская жизнь]. There was broad propaganda outlining the "sacred struggle" of two opposing principles, slavism and germanism, in which the former represents "culture and the sacred truth" and the latter, brute force of the armoured fist.

Projecting various negative stereotypes on the enemy is a psychological pattern for manufacturing the image of the enemy during wartime. The framework of perception, the psychological foundation for stereotypes, is the readiness to perceive a phenomenon or a subject in a certain way, making it fit a context or prior experience [Гасанов, с. 190]. Perception of Germany in Russia, affected by its growing military and economic power, had changed at the turn of the $19^{\text {th }}$ and $20^{\text {th }}$ centuries; it started to be associated not with philosophy and culture as before, but rather with the negative connotations and traits of Prussian culture [Эрн, с. 373-374; Лакер, c. 60-77]. The attitude toward German people in Russian popular culture, established in $18^{\text {th }}-19^{\text {th }}$ centuries, remained unchanged until the beginning of the war. By the end of the $19^{\text {th }}$ century, according to S. V. Obolenskaya, in popular culture the German remained mainly a comical figure, someone who could be easily defeated in combat [Оболенская, c. 178]. This ambivalent image of a German in the everyday perceptions of Russian people is demonstrated in proverbs recorded by V. I. Dal [Пословицы русского народа, с. 304].

There had been a traditional set of anti-German, anti-Austrian, and anti-Turkish ethnic stereotypes in the conventional perceptions of Russian people. These stereotypes were widespread and were adapted to the new conditions. The psychological mobilisation of the population and the army for fighting the external enemy had been occurring in the context of military engagement, in part spontaneously but to a greater extent purposively. This had been achieved through the transferral of various negative stereotypes onto the enemy, ultimately creating an image that dehumanizes. For instance, in the first six months of the war, about 600 various publications, 
brimming with chauvinism, were printed in Russia with the total number of copies reaching 11 million [Булдаков, 1998, с. 23].

Official patriotic propaganda created a caricature of the German enemy, as pitiful, comic, too thrifty, too pedantic, etc. [Война и народ, с. 4-6; Смех и сатира, № 34-39]. There were two general and ridiculing depictions of "typical" Germans in various patriotic publications, most importantly in luboks: firstly, the Prussians, who were depicted as corseted, with monocles and sharp-top tin hats, and secondly the Bavarians, who were depicted with large pot-bellies (due to their addiction to beer), sausages and clay pipes [Stites, p. 16]. These anti-German attitudes spread quickly and easily through negative images and stereotypes, R. Stites argues convincingly, because they were outlets for a latent anti-West perceptual framework in the Russian consciousness, shared both by common people and the elite [Ibid., p. 16-17]. In fact, for centuries in Russia the word for a German, nemets, had meant anybody from Western and Central Europe.

The Russian army's main enemy had always been the German army. Germans had lived in Russia for hundreds of years and were known to Russians better than other groups of people. Further, there was a tradition of perceiving the German in folk culture, and Germans had used internationally prohibited practices and conventions to wage war against the Russian army. Each of the previous reasons converge to intensify negative stereotypes of the image of the German, which were embodied ultimately by the figure of Wilhelm II. He had been selected as the key target for mockery. Franz Joseph and the Sultan of Turkey took second and third place respectively [Хубертус, с. 383-385]. About $30 \%$ of patriotic postcards exclusively depicted Wilhelm II; he was also the main antihero of comic luboks, in which the kaiser was presented as the representative of the entire nation [Там же, с. 384]. Wilhelm II had been depicted as the antichrist not only on lubok pictures, postcards, but also in cinematography; in the film, "Disgrace of the $20^{\text {th }}$ Century or the Antichrist", he was presented as a monster committing unthinkable crimes [Там же, с. 385]. The satirical kinoluboks, Mars's Stepson, Napoleon Inside Out, Tale of a Sorry German Soldier etc., enjoyed broad popularity during the first part of the war [Гинзбург, с. 200]. "Lubok pictures and placards, of which millions of copies were distributed in 1914 and early 1915, were drafted in popular language and constructed following the folklore narrative that heroes always win, evil punished, the good triumphs and "the Russian spirit" prevails over dark forces" [Некрылова, с. 116].

Propaganda of this sort, which influenced the creation of the image of the German enemy in soldiers' minds in the initial period of war, is corroborated by the existence of similar motifs in military folk poetry and World War I military songs [Солдатские песни, с. 7-16; Солдатские военные песни, с. 6-66]. Military soldiers' songs in folklore depicted in patriotic lubok format, related the events of the war and the operations of the forces. The song, "From over the forest..." intoned, "As we reach the Berlin town there will be not even a trace of Germans left. We will come 
back to our home forests, leading Wilhelm home by his whiskers!" [Солдатские военные песни, с. 25]. At the same time even in these patriotic songs, some of which were written by soldiers in lower ranks, there can be found direct and indirect acknowledgment of the enemy's strength: "The enemy is strong, crafty, it's not your Chinese bandit - If you drop a clanger, boy, - You'll be in trouble" [Там же, c. 41], or "A German is scary to look at, but a Russian's stronger" [Там же, с. 11].

Soldiers' poems and songs drew a satirical image of Wilhelm and his soldiers. The latter were depicted as deceitful, greedy, proud, thieving, pillaging, violent against peaceful people, and prone to commit other sins [Там же, с. 32-35]. For instance, in "Wilhelm's Song", the kaiser admits, "My soldiers are very good, - there are no better in the world, - It's just they are thieves and quick to pillage" [Там же, c. 34]. It is interesting that in the "Cossacks' Song" there are lines confirming the stereotype of the beerloving German, which was originally spread by official propaganda. The author of the song addresses the German enemy: "Get a move on, red ears! This, brother, isn't beer!" [Там же, c. 10].

Soldiers and peasants did not have clear ideas of the reality of Russia's foreign politics at the turn of the $19^{\text {th }}-20^{\text {th }}$ centuries and, in many respects, preserved the archaic perception of a foreign aggressor as "un-Christian"4. F. Stepun, a philosopher who served as an ensign gunner during the war, stated that often peasant soldiers did not know the religion of the enemy and were frequently bewildered to find they were Christian, as it did not fit their idea of an "un-Christian", "heathen" enemy [Степун, c. 270].

Aspects of traditional perceptions in the new conscripts made it difficult for them to be swayed effectively, firstly by officially declared objectives of the war and secondly by characteristics of the enemy articulated in the language of educated classes. It is hard to agree with V. P. Buldakov who writes that soldiers received no explanation of Russia's objectives in the war from either officers or clergy [Булдаков, 1997, с. 29]. When explaining war objectives, issued in orders from military command, the enemy's traits and characteristics were read out to the soldiers. For instance, Order № 1 from the Commander in Chief of the Northwest Front, General Ya. G. Zhilinsky, dated 20 July (2 August) 1914, stated: "We must defend our motherland and the honour of our arms. It is not the first time our troops are fighting the Germans. They have tested us in combat in 1757 and 1812, and we have always prevailed. I am convinced that the regiments entrusted to me will demonstrate their natural valour in this war and as always will fulfil their duty honestly and selflessly" [Сенявская, 2006, с. 65]. The order for the $2^{\text {nd }}$ Army dated 4 June 1915 states: "In this war against the Germans, the age-old enemy of the Slavs, we are fighting to protect the greatest thing we have ever been entrusted to protect: the honour and integrity of Great Russia" [Там же].

A. I. Denikin stated that officers avoided explaining the war's causes and objectives to the soldiers, either out of fear of reprisals or in order to follow

${ }^{4}$ On the Russian archetype of a foreign aggressor see [Чудинов, с. 359-361]. 
the Imperial Decree issued just before the war, which prohibited military officials from having any conversations on contemporary political subjects, including foreign politics. However, he also admitted to having violated this decree, as did many others [Деникин, с. 98]. Primary sources demonstrate how the officers failed to successfully explain objectives, partly due to the lack of conceptual framing for the peasants, keeping them from "capturing" the arguments presented by educated officers [Степун, с. 270-271; Брусилов, с. 71-72; Оськин, с. 73]. Clergy in their explanations of the causes and characteristics of the war were unable to avoid a religious interpretative framework, reiterating appeals to serve God and tsar, "to bravely go to battle for tsar, sacred Russia, and Orthodox Christian faith" [Мезенцев, c. 72]. They emphasized in their explanations how violence against the enemy was permissible, even though such statements contradicted the commandments: "thou shalt not kill" and "love thy enemy".

Sometimes the officers' and clergy's propaganda appealed to popular experience, situations and images familiar to peasants. According to memoirs of the soldier, D. Oskin, Colonel of the $11^{\text {th }}$ Tula Regiment Muzeus, in his address to the soldiers, he says: "German dominance has been so strong until now that we had almost no estate in which the manager was not a German causing serious problems for the people" [Оськин, с. 75]. This kind of propaganda was superimposed upon and processed with the peasant soldiers' traditional distrust and animosity towards officials and wealthy upper classes, amongst whom were counted many ethnic Germans. A good example of such processing would be a typical explanation of the causes of the war, widespread among the soldiers between 1914-1915, related in the memoirs of the World War I private, A. Pireyko. According to his account, the Germans are the main perpetrators of the war, "having come to Russia taking the best positions at factories, plants, and even in the army because the Tsarina is German. However, this was not enough for the Germans, and they started the war to prevail over Russia and to take total possession over the country" [Пиренко, с. 35].

Dehumanizing trends in the development of technology manifested devastatingly during World War I. Weapons of mass destruction aimed at the total annihilation of the enemy had been used for the first time in human history. For instance, the German army used poisonous gas against the Russians on December $26^{\text {th }} 1914$ [Документы о немецких зверствах, c. 42]. In doing so, they violated international rules and conventions, since such brutal weapons were banned by international treaties (the Hague Conventions of 1899 and 1907 etc.) from the first days of the war. This resulted in a wave of anti-German attitudes both on the frontlines and the rear. In the "Black Book of German Atrocities", published in Petrograd in 1914, the following passage appeared: "Bearers of the German spirit... have fallen to the state of robber, savage, and rapist of women, torturer of children and old people. These people have no altar; the spirit has left them, and there are no cannons capable of protecting them from disintegration; they'll drown in tears and blood of innocents; they declared their own condemnation. 
Feelings of vengeance are alien to us, Russians, but it is our duty and our obligation to mete the just punishment for the evil deeds committed by the Germans" [Черная Книга германских зверств, с. 3]. The subject of German atrocities and cruelty appeared frequently in the press. The Moscow Gazette, for instance, in the header, "Topics of the Day", published numerous witness statements of cruelty demonstrated by the German enemy and drew the following conclusion: "The conduct of these despicable people can be clearly and succinctly defined by two words: beastliness and skulduggery” [Московские ведомости, 1914, № 232].

The majority of soldiers did not read periodicals being content with lubok pictures, which not only reaffirmed their first-hand experience of the enemy's cruelty but also reinforced their general perceptions of the Germans. One such example is described in the campaign diary of Dr. L. Voytololvsky, an army physician. He witnesses the following episode in August 1915: "The clear sky is swarming with German airplanes. There are lots of them. They are dropping bombs that explode all over the place and fill the air with piercing metallic racket. Next to us there are Cossacks of the Yekaterinburg regiment taking a rest. Lounging on the grass they are looking at the flying machines with scorn and engaged in a calm discourse.

'For sending these airplanes', says the massive tanned guy, 'we should break all the ribs of these Germans, and that's being too kind...'

'There are no dirtbags worse than the Germans', the other responds, 'they thought of everything for killing. Gas, airplanes, cannons...'

'The war has taught everybody', an elderly Cossack joins with a sigh, 'No shame, no conscience. We mow down people as if they were meadow grass...'

'That's what I'm saying', responds the first Cossack, 'One climbs up there and ... drops bombs like turds. Another spits at him with shrapnel. What for? Who needs this? Only the devil knows!..' [Войтоловский, с. 383].

Due to ineffective management, lack of the coordination between different parts of the state, shortages of arms and ammunition and battles lost on the frontlines, as early as the first year of the war, rumours circulated among soldiers of treason in the top echelons of power, of German spies and "German domination". According to L. Voytolovsky, in August 1914 soldiers, knowing neither the name of the regiment commander nor the regiment to which they were attached, had been passing around trusted statements in conversations like the following: "You see what cunning thing! The regiment commander is a German, defected to their side. That's why they march us back and forth until we're exhausted, torturing us, driving the last bits of strength out..." [Там же, c. 9].

The word nemets (a German) was gradually becoming a symbol, a verbal construct, which in 1915-1917 had a meaning in the common soldiers' perception not only of an external enemy but the enemy's internal accomplices, who hindered Russia's effective performance at the front and mobilisation at rear. The nationalist propaganda in literature and periodicals associated German dominance with a soulless bureaucrat, the German 
coloniser, a manager of a factory or an estate [Немецкое зло, с. 3-103; Московские ведомости, № 233]. This representation of the enemy started to be associated with the image of the empress, an ethnic German, after the "great retreat" of the Russian army in 1915. In the eyes of some peasants and soldiers, the Empress Alexandra Feodorovna and the Dowager Empress Maria Feodorovna had been "German ladies" allegedly sympathising with Germany, using all possible means to harm Russia. This is corroborated by the criminal files from the $1^{\text {st }}$ Department of the $3^{\text {rd }}$ Criminal Section of the Ministry of Justice on prosecutions for obscenities uttered about the tsar and the members of the royal family. For instance a private of the $345^{\text {th }}$ Pskov Infantry Brigade, a peasant from the Pskov Guberniya, A. S. Zatravkin, a day before being conscripted in December 1914 in the village of B. Zagorye, while in conversation with girls who were knitting for the Russian army, said the following: "Напрасно вы, девушки, работаете для армии, бросьте работу, все равно вещи ваши не дойдут ни до солдата, ни до бедного офицерика, и злая Царица матерь Государя императора Мария Федоровна все ваши вещи прокутит и прогуляет со своими любовниками и развратниками"5 [РГИА, ф. 1405, оп. 521, д. 476, л. 3 об.]. Other sources reinforce such perceptions in the army. F. Stepun wrote that in 1916, "in the trenches soldiers talked openly saying that the war was sent onto Russia by the German advisors of the Sovereign Emperor having great power at the Court being backed by the very Empress who, although married to a Russian man, still toes the German line" [Степун, c. 301]. There were rumours among soldiers about treason committed by brigade, division, and regiment commanders as well as fort commandants, some who had German surnames [РГВИА, ф. 2048, оп. 1, д. 904, л. 9; Бочкарева, с. 152-153]. Poor military management, embezzlement, and the cowardice of certain officers were often attributed to treason too. Sometimes soldiers would blame German dominance for the harsh discipline in the army. One of the soldier's letters, dated November 1915, states: "У нас в пехоте введена жестокая порка за всякий маловажный проступок солдата... А это есть плод немецких козней и измышления" 6 [РГВИА].

The perceived stereotype of the German enemy, who had always been beaten by the Russians, was soon dispelled on the battlefield where the Russian army experienced the full weight of the German "armoured fist". Having personally experienced the deadly force of German military weaponry, especially at the time of shortages of the most basic arms, heavy artillery, munitions, rifles, and cartridges between 1914-1915, Russian soldiers suffered a serious psychological shock. In contrast to the caricatural image represented by propaganda, soldiers came face to face with the German, who in their eyes was a capable adversary, with nearly superhuman attributes,

\footnotetext{
5 "You, girls, are working for the army in vain, give it up, the things you make will never get to soldiers or poor officers and the evil Tsarina, Mother of the Sovereign Emperor Maria Feodorovna will waste all these things bingeing with her reprobate women-chasing lovers".

6 "In the infantry they introduced barbaric beatings for any minor offence a soldier is found guilty of... And this is the fruit of German machinations and fabrications".
} 
possessing an impressive mind, will, and even magical abilities, which were unattainable to the Russians. S. Z. Fedorchenko, a nurse who had kept records of soldiers' conversations ${ }^{7}$, witnessed a discourse on this subject, demonstrating the strength and profoundness of this psychological phenomena: "A German's head is like clockwork. Oil it well, and it'll work just lovely, no bother. And us?... First of all we get beatings, lots of 'em. To this day when I sleep all I see is beatings"; "Everyone is giving praise to the Germans now. We reckon now that a German and a wise man are one and the same thing.... It all started with us being stupid.... As the saying goes, he is a brave man amongst sheep, but a sheep when set against a brave man"; "The Germans know this very well. Everything works out with them, not like us. There are no faults in their clothes, drink, food, or arms wherever you look... And what is it that they have? Maybe we could find it, but we were not given an order to do it" [Федорченко, с. 84, 88-90].

These sentiments reflect perceptions of the adversary's superiority, and similar verbal constructs were reported by L. N. Voytolovsky, who recorded the following conversation in October 1914:

"So, do you think we will prevail over the Germans?" the adjutant asks. "Well... we should", says the stubbly infantry private without conviction. "It's just, you see, they have so many cannons. When they start blanket bombing with shrapnel, you can't see the sky... "You can't prevail over the Germans with just a straw. See the training they get, and us?... War or no war Germans are taught everything from a young age and know what's what and how. Their clothes, and food, and cannons are all different from ours. Everything works out with them, not like us!... No! The Germans won't lose!" [Войтоловский, с. 74]. "How could we fight the Germans? No way - their soldiers are well fed, shod, clothed, and washed, and soldiers have good thoughts. What do WE have? No order, they are just tiring the people for no good reason" [Арамилев, с. 539].

Data from other sources confirm that these perceptions were not rare. A content analysis of letters intercepted by the Military Censor Committee of the Kazan Military District from 1915 to early $1917^{8}$ demonstrate that these types of statements took third highest position of the most frequently recited criticism in soldiers' letters from 1915. This category of statements includes firstly, assertions of the superiority of the German military and technology and secondly, assertions of treachery and corruption in the top military command and in governmental officials, either who were bribed allegedly by the Germans (particularly those who sold Russian lands to the Germans) or who were ethnic Germans, which, according to the authors of these letters, caused the Russian army to lose the war (9.8\% each) [Поршнева, с. 195-196]. In 1916 there was a significant increase (from $1.6 \%$ in 1915 to $4 \%$ ) of the share of statements that Russia cannot win the war

\footnotetext{
7 We share the opinion of a number of authors on authenticity of these records. See: [Поршнева, с. 308-324].

${ }^{8}$ Dangerous letters attached to censors' reports are published in the collection [Царская армия в период мировой войны и Февральской революции, с. 24-160].
} 
against Germany. Moreover, $3.6 \%$ of this category of statements insisted that the enemy was not outside, but inside the country [Там же, с. 209].

Belief in German military and technical superiority was typical for the officer ranks in the Russian army. The Head of the British Military Mission, General A. Knox, wrote the following in August 1915: "You cannot but be amazed at how many outstanding commanders are so mortified by the conviction of the technical superiority of the Germans; they believe that Germans 'can do anything"' [цит. по: Головин, т. 2, с. 142]. Perceptions of German military power conversely reflected back upon a lack of confidence in their own weaponry. This confidence or the lack of it is one of the factors determining the army's state of morale. P. I. Izmestyev, a military psychologist, admitted: "We had no confidence in ourselves, in our own weaponry, being mesmerized by the power of the Germans" [Изместьев, c. 9].

As the war continued, the tendency of "humanizing" the image of the German became more pronounced in soldiers' minds, moving away from stereotypes imposed by official propaganda and cultural traditions. This change occurred because of the common situations experienced by privates, who served on both sides, especially as they came into direct contact with each other, in the beginning either in hand-to-hand combat, as POWs, or as wounded enemy soldiers who received care and attention, and later during periods of mutual visits to the trenches on Christian holidays or general fraternization, etc. Particularly influential on attitudes towards the enemy was the effect of fraternization, which occurred for the first time during Christmas 1915-1916, Christmas 1916-1917, and also Easter 1916, when soldiers exchanged food, gifts, and visited each other's trenches [Солдатские письма в годы мировой войны, с. 148-155]. Russian soldiers were impressed by the tidiness and comfort of German trenches. German provisions and alcoholic beverages appeared to be of better quality, which only served to reinforce their belief in the material and technical superiority of the enemy. The press published first-hand accounts of journalists who visited hospitals: "The Russian wounded speak of German POWs without hatred. You always hear: 'They are people, the same as us'" [Петроградские ведомости].

The common soldiers' consciousness underwent the intensive process of focusing perceptions of evil onto the figure of the inner enemy while at the same time "humanizing" the image of the external enemy. The following soldier's reasoning was typical in letters of criticism intercepted by censors: "Did we come here so that our homes are ravaged? No, nobody ever thought that; We went hoping to protect the fatherland against the external enemy and forgot about the inner enemy, but he is not far removed" [Царская армия в период мировой войны и Февральской революции, с. 119], "There are no German or Turkish beasts; they are people, the same as us; their wives, mothers, fathers suffer just as much as you. They were sent to fight by the fat masters and officer bosses. They are the ones who need the war, not us" [Там же, с. 81]. 
The broadening of soldiers' horizons affected the perception of the external German enemy; some of them, particularly workers, had read socialist literature prior to the war. Legal left-liberal papers published during the war argued that simple German folk were not to blame for the initiation of the military conflict [Зауральский край]. A gradual transformation of the image of the external enemy as "beast" to the image of the enemy as human occurred. This was corroborated indirectly by the decline of the satirical genre of lubok, the genre used earlier to dehumanize the enemy, which by 1915 had stopped being published [Hubertus, p. 25]. Many testimonies of such attitudes can be found in memoirs, which recorded typical soldiers' thoughts and reflections. S. Z. Fedorchenko quoted the following monologue: "His bosses sent him here, like us. Tore him away from everything. Where's the wife? Where's the house? Where's his mother? Us and them are both without guilt. It is even harder for him; they say their homes are very nice. Hard to leave" [Федорченко, с. 81]. The campaign diary of L. Voytolovsky records a similar statement: "German did me no harm... and there's no point in fighting” [Войтоловский, с. 74].

The crisis of confidence in the government and the course of the war itself changed the attitude of Russian soldiers towards their allies, driving them to further disappointment. There was a widespread perception of Great Britain as the main culprit in the war and the key enemy of the Russian people, which also had been reinforced by German propaganda as it aimed at the systematic corruption of morale in Russian troops. Regardless of the increase in antiGerman attitudes in Russian society from 1916 to 1917, and then a temporary revival of the military enthusiasm during the February Revolution in 1917, this trend of the inversion of the image of the external enemy had manifested with an immense force with the development of the events in spring-autumn of 1917, when it was not Germany / the Germans but England / the English and other allies as well as the bourgeoisie which had turned into the enemies of the Russian people in the perception of the Russian soldier.

Альбом героев войны. 1914. № 1.5 с. [Al’bom geroev vojny, 1914. N 1.5 s.]

Армилев В. В дыму войны // Первая мировая (История Отечества в романах, повестях, документах. Век XX.). M., 1989. С. 566. [Armilev V. V dymu vojny // Pervaya mirovaya (Istoriya Otechestva v romanakh, povestyakh, dokumentakh. Vek XX.). M., 1989. S. 566.]

Беркевич А. Б. Крестьянство и всеобщая мобилизация в июле 1914 г. // Исторические записки. 1947. Т. 23. С. 3-43. [Berkevich А. B. Krest'yanstvo i vseobschaya mobilizatsiya v iyule 1914 g. // Istoricheskie zapiski. 1947. T. 23. S. 3-43.]

Бочкарева М. Яшка: моя жизнь крестьянки, офицера и изгнанницы. В записи Исаака Дон Левина. М., 2001. 445 с. [Bochkareva M. Yashka: moya zhizn' krest'yanki, ofitsera i izgnannitsy. V zapisi Isaaka Don Levina. M., 2001. 445 s.]

Брусилов А. А. Мои воспоминания. М. ; Л., 1929. 250 с. [Brusilov A. A. Moi vospominaniya. M. ; L., 1929. 250 s.]

Булдаков В. Красная смута. Природа и последствия революционного насилия. М., 1997. 376 c. [Buldakov V. Krasnaya smuta. Priroda i posledstviya revolyutsionnogo nasiliya. M., 1997. 376 s.]

Булдаков В. П. Первая мировая война и имперство // Первая мировая война. Пролог ХX века. М., 1998. С. 21-25. [Buldakov V. P. Pervaya mirovaya vojna i imperstvo // Pervaya mirovaya vojna. Prolog XX veka. M., 1998. S. 21-25.] 
Война и народ. Юмористический и сатирический альманах. M., 1915. 8 с. [Vojna i narod. Yumoristicheskij i satiricheskij al'manakh. M., 1915. $8 \mathrm{~s}$.]

Войтоловский Л. Н. Всходил кровавый Марс: по следам войны. М., 1998. 430 с. [Vojtolovskij L. N. Vskhodil krovavyj Mars: po sledam vojny. M., 1998. 430 s.]

Гасанов И. Национальные стереотипы и «образ врага» // Психология национальной нетерпимости : хрестоматия / сост. Ю. В. Чернявская. Минск, 1998. С. 187-208. [Gasanov I. Natsional'nye stereotipy i «obraz vraga» // Psikhologiya natsional'noj neterpimosti : khrestomatiya / sost. Yu. V. Chernyavskaya. Minsk, 1998. S. 187-208.]

Гинзбург С. Кинематография дореволюционной России. М., 1963. 404 с. [Ginzburg S. Kinematografiya dorevolyutsionnoj Rossii. M., 1963. 404 s.]

Головин Н. Н. Военные усилия России в мировой войне : в 2 т. Париж, 1939. Т. 2. 242 c. [Golovin N. N. Voennye usiliya Rossii v mirovoj vojne : v 2 t. Parizh, 1939. T. 2. 242 s.] Голубев А. В., Поринева О. С. Образ союзника в сознании российского общества в контексте мировых войн. М., 2012. 392 c. [Golubev A. V., Porshneva O. S. Obraz soyuznika v soznanii rossijskogo obschestva v kontekste mirovykh vojn. M., 2012. 392 s.]

Деникин А. И. Очерки Русской Смуты. Крушение власти и армии, февральсентябрь 1917. М., 1991. 520 c. [Denikin A. I. Ocherki Russkoj Smuty. Krushenie vlasti i armii, fevral'-sentyabr' 1917. M., 1991. 520 s.]

Документы о немецких зверствах в 1914-1918 гг. М., 1942. 80 с. [Dokumenty о nemetskikh zverstvakh v $1914-1918$ gg. M., 1942.80 s.]

Зауральский край. 1914. 6 декабря. [Zaural'skij kraj. 1914. 6 dekabrya.]

Изместьев П. И. Очерки по военной психологии. (Некоторые основы тактики и военного воспитания.) Петроград, 1923. 102 c. [Izmest'ev P. I. Ocherki po voennoj psikhologii. (Nekotorye osnovy taktiki i voennogo vospitaniya.) Petrograd, 1923. $102 \mathrm{~s}$.]

Кирьянов Ю. И. Рабочие России и война: новые подходы к анализу проблемы // Первая мировая война: Пролог XX века. М., 1998. С. 432-445. [Kir’yanov Yu. I. Rabochie Rossii i vojna: novye podkhody $\mathrm{k}$ analizu problemy // Pervaya mirovaya vojna: Prolog XX veka. M., 1998. S. 432-445.]

Колоницкий Б. И. Политические функции англофобии в годы Первой мировой войны // Россия и Первая мировая война (Материалы международного научного коллоквиума). СПб., 1999. С. 271-287. [Kolonitskij B. I. Politicheskie funktsii anglofobii v gody Pervoj mirovoj vojny // Rossiya i Pervaya mirovaya vojna (Materialy mezhdunarodnogo nauchnogo kollokviuma). SPb., 1999. S. 271-287.]

Колоницкий Б. И. «Трагическая эротика»: Образы императорской семьи в годы Первой мировой войны. М., 2010. 664 с. [Kolonitskij B. I. «Tragicheskaya erotika»: Obrazy imperatorskoj sem'i v gody Pervoj mirovoj vojny. M., 2010. 664 s.]

Лакер У. Россия и Германия наставники Гитлера. Вашингтон, 1991. 485 c. [Laker U. Rossiya i Germaniya nastavniki Gitlera. Vashington, 1991. 485 s.]

Мезенцев Е. В. Вера и мужество. Из истории российского военного духовенства // Отечество : краеведческий альманах. Вып. 12. (2-е полугодие 1997 г.) М., 1997. C. 53-84. [Mezentsev E. V. Vera i muzhestvo. Iz istorii rossijskogo voennogo dukhovenstva // Otechestvo : kraevedcheskij al'manakh. Vyp. 12. (2-e polugodie 1997 g.) M., 1997. S. 53-84.]

Московские ведомости. 1914. 7 октября, № 232. [Moskovskie vedomosti. 1914. 7 oktyabrya, N 232.]

Московские ведомости. 1914. 8 октября, № 233. [Moskovskie vedomosti. 1914. 8 oktyabrya, N 233.]

Некрылова А. Ф. Русские народные городские праздники, увеселения и зрелища: Конец XVIII - нач. XX в. Л., 1988. 215 c. [Nekrylova A. F. Russkie narodnye gorodskie prazdniki, uveseleniya i zrelischa: Konets XVIII - nach. XX v. L., 1988. 215 s.]

Немецкое зло : сб. ст., посвящ. вопросу о борьбе с нашей «внутренней Германией». Вып. 1. М., 1915. 117 c. [Nemetskoe zlo : sb. st., posvyasch. voprosu o bor'be s nashej «vnutrennej Germaniej». Vyp. 1. M., 1915. 117 s.]

Носков В. В. Первая мировая война и русская идея // Диалог со временем. Альманах интеллектуальной истории. 25/2. М., 2008. C. 50-87. [Noskov V. V. Pervaya mirovaya vojna i russkaya ideya // Dialog so vremenem. Al'manakh intellektual'noj istorii. 25/2. M., 2008. S. 50-87.]

Оболенская С. В. Образ немца в русской народной культуре XVIII-XIX вв. // Одиссей. Человек в истории. Культурно-антропологическая история сегодня. М., 1991. C. 160-185. [Obolenskaya S. V. Obraz nemtsa v russkoj narodnoj kul'ture XVIIIXIX vv. // Odissej. Chelovek v istorii. Kul'turno-antropologicheskaya istoriya segodnya. M., 1991. S. 160-185.] 
Оренбургская жизнь. 1914. 26 августа, 24 сентября. [Orenburgskaya zhizn' 1914. 26 avgusta, 24 sentyabrya.]

Оськин Д. Записки солдата. М., 1929. 333 с. [Os'kin D. Zapiski soldata. M., 1929. 333 s.]

Пермские ведомости. 1914 г. 1, 8 августа. [Permskie vedomosti. 1914 g. 1, 8 avgusta.]

Петроградские ведомости. 1914. 25 августа (5 сентября). № 190. [Petrogradskie vedomosti. 1914. 25 avgusta (5 sentyabrya). $\mathrm{N}$ 190.]

Пирейко А. На фронте империалистической войны. Воспоминания большевика. M., 1935. 101 c. [Pirejko A. Na fronte imperialisticheskoj vojny. Vospominaniya bol'shevika. M., 1935. 101 s.]

Поршнева О. С. Крестьяне, рабочие и солдаты России накануне и в годы Первой мировой войны. М., 2004. 368 с. [Porshneva O. S. Krest'yane, rabochie i soldaty Rossii nakanune i v gody Pervoj mirovoj vojny. M., 2004. 368 s.]

Пословищы русского народа : сб. В. И. Даля : в 2 т. М., 1989. Т. 1. [Poslovitsy russkogo naroda : sb. V. I. Dalya : v 2 t. M., 1989. T. 1.]

РГВИА. Ф. 2048. [RGVIA. F. 2048.]

РГИА Ф. 1405. [RGIA F. 1405.]

Россия борется за правду. М., 1914. 32 с. [Rossiya boretsya za pravdu. M., 1914. 32 s.]

Россия в мировой войне 1914-1918 гг. (в цифрах). М., 1925. 103 с. [Rossiya v mirovoj vojne 1914-1918 gg. (v tsifrakh). M., 1925. $103 \mathrm{s.}$ ]

Сенявская E. C. Образ врага в сознании участников Первой мировой войны // Вопр. истории. 1997. № 3. С. 140-145. Senyavskaya E. S. Obraz vraga v soznanii uchastnikov Pervoj mirovoj vojny // Vopr. istorii. 1997. N 3. S. 140-145.

Сенявская E. С. Противники России в войнах XX века: Эволюция «образа врага» в сознании армии и общества. М., 2006. 288 c. [Senyavskaya E. S. Protivniki Rossii v vojnakh XX veka: Evolyutsiya «obraza vraga» v soznanii armii i obschestva. M., 2006. 288 s.]

Сенявская Е. С. Психология войны в XX веке: исторический опыт России. М., 1999. 383 c. [Senyavskaya E. S. Psikhologiya vojny v XX veke: istoricheskij opyt Rossii. M., 1999. $383 \mathrm{s.}]$

Сергеев Е. Ю. Образ Великобритании в представлении российских дипломатов и военных в конце XIX - начале XX века // Россия и Европа в XIX-XX вв. Проблемы взаимовосприятия народов, социумов, культур. М., 1996. С. 166-174. [Sergeev E. Yu. Obraz Velikobritanii v predstavlenii rossijskikh diplomatov i voennykh v kontse XIX nachale XX veka // Rossiya i Evropa v XIX-XX vv. Problemy vzaimovospriyatiya narodov, sotsiumov, kul'tur. M., 1996. S. 166-174.]

Смех и сатира. 1914. № 34-39. [Smekh i satira. 1914. N 3439.]

Солдатские военные песни Великой Отечественной войны 1914-1915 гг. Харбин, 1915. 70 c. [Soldatskie voennye pesni Velikoj Otechestvennoj vojny 1914-1915 gg. Kharbin, 1915. $70 \mathrm{s.}]$

Солдатские песни : сб. военных песен. Ярославль, 1915. 16 c. [Soldatskie pesni : sb. voennykh pesen. Yaroslavl', 1915. 16 s.]

Солдатские письма в годы мировой войны (1915-1917 гг.) // Красный архив. М., 1934. T. 4-5. [Soldatskie pis'ma v gody mirovoj vojny (1915-1917 gg.) // Krasnyj arkhiv. M., 1934. T. 4-5.]

Степун Ф. Бывшее и несбывшееся. СПб., 1994. 651 с. [Stepun F. Byvshee i nesbyvsheesya. SPb., 1994. 651 s.]

Тютюкин С. В. Первая мировая война и революционный процесс в России (Роль национально-патриотического фактора) // Первая мировая война: Пролог XX века. M., 1998. C. 236-249. [Tyutyukin S. V. Pervaya mirovaya vojna i revolyutsionnyj protsess v Rossii (Rol' natsional'no-patrioticheskogo faktora) // Pervaya mirovaya vojna: Prolog XX veka. M., 1998. S. 236-249.]

Уральская жизнь. 1914. 22 июля. [Ural'skaya zhizn'. 1914. 22 iyulya.]

Федорченко С. З. Народ на войне. М. ; Л., 1925. 127 с. [Fedorchenko S. Z. Narod na vojne. M. ; L., 1925. 127 s.]

Ферстер С. Тотальная война. Концептуальные размышления к историческому анализу структур эпохи 1861-1945 гг. // Опыт мировых войн в истории России. Челябинск, 2007. C. 12-27. [Ferster S. Total'naya vojna. Kontseptual'nye razmyshleniya k istoricheskomu analizu struktur epokhi 1861-1945 gg. // Opyt mirovykh vojn v istorii Rossii. Chelyabinsk, 2007. S. 12-27.]

Хубертус Ян. Ф. Русские рабочие, патриотизм и Первая мировая война // Рабочие и интеллигенция России в эпоху реформ и революций. 1861 - февраль 1917 г. М., 1997. C. 379-396. [Khubertus Yan. F. Russkie rabochie, patriotizm i Pervaya mirovaya vojna 
// Rabochie i intelligentsiya Rossii v epokhu reform i revolyutsij. 1861 - fevral' 1917 g. M., 1997. S. 379-396.]

Царская армия в период мировой войны и Февральской революции. Материалы к изучению истории империалистической и гражданской войны. Казань, 1932. 239 с. [Tsarskaya armiya v period mirovoj vojny i Fevral'skoj revolyutsii. Materialy k izucheniyu istorii imperialisticheskoj i grazhdanskoj vojny. Kazan', 1932. 239 s.]

Царские слова к русскому народу. Высочайшие манифесты об объявлении войны с Германией и Австро-Венгрией. Петроград, 1914. 1 c. [Tsarskie slova k russkomu narodu. Vysochajshie manifesty ob ob'yavlenii vojny s Germaniej i Avstro-Vengriej. Petrograd, 1914. 1 s.]

Черная Книга германских зверств / под ред. и со вступ. ст. д-ра М. В. Головинского. Петербург, 1914. 55 c. [Chernaya Kniga germanskikh zverstv / pod red. i so vstup. st. d-ra M. V. Golovinskogo. Peterburg, 1914. 55 s.]

Эрн В. Ф. Время славянофильствует. Война, Германия, Европа и Россия // Эрн В. Ф. Соч. M., 1991. C. 369-398. [Ern V. F. Vremya slavyanofil'stvuet. Vojna, Germaniya, Evropa i Rossiya // Ern V. F. Sochineniya. M., 1991. S. 369-398.]

Hubertus J. F. Patriotic Culture in Russia during World War I. Washington, D.C., 1991. $330 \mathrm{p}$.

Hubertus F. J. Patriotic Culture in Russia during World War I. Ithaca ; London, 1995. $229 \mathrm{p}$.

Lipp A. Meinunglenkung im Krieg: Kriegserfahrungen deutscher Soldaten und ihre Deutung 1914-1918. Göttingen : Vandenhoeck \& Ruprecht, 2003. 354 S.

Liulevicius V. G. War Land on the Eastern Front. Culture, National Identity, and German Occupation in World War I. Cambridge : Univ. Press, 2000. 309 p.

Norris S. M. A War of Images. Russian Popular Prints, Wartime Culture, and National Identity, 1812-1945. Illinois, 2006. P. 135-163.

Stites R. Days and Nights in Wartime Russia: Cultural Life, 1914-1917 // European Culture in the Great War. Cambridge, 1999. P. 8-31. $316 \mathrm{p}$.

Ziemann B. War Experiences in Rural Germany. 1914-1923. Oxford ; New York, 2007.

Translated by Mikhail Kriviniouk

The article was submitted on 27.12.2013

Ольга Сергеевна Поршнева, проф. Olga Porshneva, prof.

Россия, Екатеринбург

Уральский федеральный

Russia, Yekaterinburg

университет

porshneva@yandex.ru

Ural Federal University

porshneva@yandex.ru 